\title{
Effect of sintering temperature and sintering additives on ionic conductivity of $\mathrm{LiSi}_{2} \mathrm{~N}_{3}$
}

\author{
Eiichirou NARIMATSU, ${ }^{\dagger}$ Yoshinobu YAMAMOTO, Toshiyuki NISHIMURA and Naoto HIROSAKI
}

Non-Oxide Ceramics Group, Nano-Ceramics Center, National Institute for Materials Science, 1-1 Namiki, Tsukuba, Ibaraki 305-0044

\begin{abstract}
The effect of sintering temperature and sintering additives on the ionic conductivity of $\mathrm{LiSi}_{2} \mathrm{~N}_{3}$ was studied by performing complex impedance measurements. $\mathrm{LiSi}_{2} \mathrm{~N}_{3}$ materials were fabricated by the reaction of $\mathrm{Li}_{3} \mathrm{~N}, \mathrm{Si}_{3} \mathrm{~N}_{4}$, and sintering additives at temperatures of 1873-2073 K. Dense hot-pressed bodies were obtained at 1973-2073 K in the case of undoped $\mathrm{LiSi}_{2} \mathrm{~N}_{3}$ and at $1873 \mathrm{~K}$ in the case of $\mathrm{Y}_{2} \mathrm{O}_{3}, \mathrm{CaF}_{2}$, and $\mathrm{B}_{2} \mathrm{O}_{3}$ addition. The ionic conductivity increased greatly with increasing sintering temperature and exhibited a strong dependence on the type of sintering additive. When the sintering temperature was constant at $1873 \mathrm{~K}$, although the conductivities of $\mathrm{Y}_{2} \mathrm{O}_{3}$-doped $\mathrm{LiSi}_{2} \mathrm{~N}_{3}$ and $\mathrm{CaF}_{2}-\mathrm{doped} \mathrm{LiSi}_{2} \mathrm{~N}_{3}$ were lower than that of undoped $\mathrm{LiSi}_{2} \mathrm{~N}_{3}$, the conductivity of $\mathrm{B}_{2} \mathrm{O}_{3}$-doped $\mathrm{LiSi}_{2} \mathrm{~N}_{3}$ was higher than that of undoped $\mathrm{LiSi}_{2} \mathrm{~N}_{3}$. The enhanced conductivity of $\mathrm{B}_{2} \mathrm{O}_{3}$-doped $\mathrm{LiSi}_{2} \mathrm{~N}_{3}$ can be attributed to the increase in the density of the sintered material without the formation of a phase of significant resistance at the grain boundaries.
\end{abstract}

(C2010 The Ceramic Society of Japan. All rights reserved.

Key-words : Electrical properties, Impedance, Ionic conductivity, Nitrides, Batteries

[Received March 29, 2010; Accepted August 19, 2010]

\section{Introduction}

Lithium solid electrolytes are of considerable interest for the production of solid-state lithium batteries. Among the binary and ternary lithium nitrides, $\mathrm{Li}_{3} \mathrm{~N}$ has the highest lithium ion conductivity of about $10^{-3} \Omega^{-1} \cdot \mathrm{cm}^{-1}$. ${ }^{1)}$ However, the decomposition voltage of $\mathrm{Li}_{3} \mathrm{~N}$ has a rather low value of $0.44 \mathrm{~V}$ at room temperature, and it decreases rapidly with increasing temperature. ${ }^{1)}$ Thus, the applicability of binary lithium nitride as a solidstate electrolyte at elevated temperatures is limited. To compensate for this disadvantage, several ternary lithium nitrides have been investigated and their lithium ion conductivity has been measured. ${ }^{2)-6)}$

Ternary lithium silicon nitrides are examples of such interesting materials. Among the $\mathrm{Li}_{3} \mathrm{~N}-\mathrm{Si}_{3} \mathrm{~N}_{4}$ systems, there are several ternary compounds, including $\mathrm{LiSi}_{2} \mathrm{~N}_{3},{ }^{4), 7), 8)} \quad \mathrm{Li}_{2} \mathrm{SiN}_{2},{ }^{4), 9), 10)}$ $\mathrm{Li}_{5} \mathrm{SiN}_{3},{ }^{4), 11), 12)} \mathrm{Li}_{18} \mathrm{Si}_{3} \mathrm{~N}_{10},{ }^{4)} \mathrm{Li}_{21} \mathrm{Si}_{3} \mathrm{~N}_{11}$, ${ }^{4}$ and $\mathrm{Li}_{8} \mathrm{SiN}_{4}$. ${ }^{4)}$ Despite the crystal structure of some of these compounds remaining unclarified, the $\mathrm{Li}^{+}$ion conductivity of lithium silicon nitride compounds tends to increase with the $\mathrm{Li} / \mathrm{Si}$ ratio. ${ }^{4), 13)} \mathrm{Li}_{8} \mathrm{SiN}_{4}$ has been reported to have the highest ionic conductivity of the above ternary lithium nitrides. ${ }^{4}$ However, it is unstable in the presence of moisture and soluble in water. ${ }^{4)}$

Among the lithium silicon nitrides, $\mathrm{LiSi}_{2} \mathrm{~N}_{3}$ is the most stable compound and has a well-defined crystal structure that is isostructural with $\mathrm{Si}_{2} \mathrm{~N}_{2} \mathrm{O}$ and $\mathrm{Li}_{2} \mathrm{SiO}_{3}$, which have a wurtzitetype structure (space group $\left.C m c 2_{1}\right)^{7), 8)}$ Similar to $\mathrm{Si}_{2} \mathrm{~N}_{2} \mathrm{O}$, the framework of $\left[\mathrm{Si}_{2} \mathrm{~N}_{3}\right]^{-}$in $\mathrm{LiSi}_{2} \mathrm{~N}_{3}$ is built up of two-dimensional infinite, parallel layers of condensed $\left[\mathrm{Si}_{6} \mathrm{~N}_{6}\right]$ twelve-membered rings formed by sharing the nitrogen atoms at the corners of the $\mathrm{SiN}_{4}$ tetrahedra. ${ }^{8} \mathrm{Li}^{+}$occupies the $4 \mathrm{a}$ site and is directly connected with four or five nitrogen atoms within the unit cell $(\sim 2.3 \AA)$ or the crossover unit cell $(\sim 2.7 \AA)$, respectively.

$\dagger$ Corresponding author: E. Narimatsu; E-mail: NARIMATSU.

Eiichirou@nims.go.jp
Regarding the practical use of the lithium silicon nitrides, $\mathrm{LiSi}_{2} \mathrm{~N}_{3}$ is of particular interest.

Therefore, in this study we focused on the most stable compound, $\mathrm{LiSi}_{2} \mathrm{~N}_{3}$. To the best of our knowledge, there have been no detailed reports on the dependence of the ionic conductivity of $\mathrm{LiSi}_{2} \mathrm{~N}_{3}$ on sintering temperature and the addition of sintering additives. Accordingly, the aim of this study is to investigate the effects of sintering temperature and the addition of sintering additives on the ionic conductivity of $\operatorname{LiSi}_{2} \mathrm{~N}_{3}$.

\section{Experimental procedure}

Undoped, $\mathrm{Y}_{2} \mathrm{O}_{3}$-doped, $\mathrm{CaF}_{2}$-doped, and $\mathrm{B}_{2} \mathrm{O}_{3}$-doped $\mathrm{LiSi}_{2} \mathrm{~N}_{3}$ were prepared by the reaction of $\mathrm{Li}_{3} \mathrm{~N}$ (>99\% purity, Kojundo Chemical Lab. Co., Ltd, Saitama, Japan), $\alpha-\mathrm{Si}_{3} \mathrm{~N}_{4}$ (SN-E10, UBE Industries, Tokyo, Japan), and a sintering additive. Three additives, $\mathrm{Y}_{2} \mathrm{O}_{3}$ (99.9\% purity, Shin-Etsu Chemical Co., Ltd, Tokyo, Japan), $\mathrm{CaF}_{2}$ (>99.9\% purity, Kojundo), and $\mathrm{B}_{2} \mathrm{O}_{3}$ (99.98\%, Aldrich, Milwaukee, WI, USA) were selected as sintering additives. $\mathrm{Li}_{3} \mathrm{~N}$ powder, $\alpha-\mathrm{Si}_{3} \mathrm{~N}_{4}$ powder, and the sintering additive were mixed using an silicon nitride mortar in a dry state. Table 1 shows the compositions of the starting powders (A-F) used in this study. The $\mathrm{Li}_{3} \mathrm{~N}$ powder and $\alpha-\mathrm{Si}_{3} \mathrm{~N}_{4}$ powder were mixed in stoichiometric compositions. The mixed powder was placed in a 26-mm-diameter graphite mold and a thin BN plate was added between the mold cap and the mixed powder to separate them. All the processes were carried out in a nitrogen-filled glove box. Hot pressing was performed at 1873, 1973 , and $2073 \mathrm{~K}$ for $1 \mathrm{~h}$ under a pressure of $20 \mathrm{MPa}$ in a $\mathrm{N}_{2}$ atmosphere $(0.10 \mathrm{MPa})$.

The crystal structure of each sample was determined by X-ray diffractometry (D8 ADVANCE, Bruker, Germany) using $\mathrm{Cu} \mathrm{K} \alpha$ radiation. The densities of the samples were measured using Archimedes' method, with distilled water as the immersion medium. The microstructures of the samples were observed by scanning electron microscopy (SEM, JSM-6700F, JEOL, Ltd., Japan). 
Table 1. Compositions, sintering temperatures, and characteristics of hot-pressed materials

\begin{tabular}{|c|c|c|c|c|c|c|c|c|}
\hline \multirow{2}{*}{ Material } & \multicolumn{5}{|c|}{ Composition of starting powder (wt \%) } & \multirow{2}{*}{$\begin{array}{l}\text { Sintering temperature } \\
\qquad(\mathrm{K})\end{array}$} & \multirow{2}{*}{$\begin{array}{l}\text { Density } \\
\left(\mathrm{g} / \mathrm{cm}^{3}\right)\end{array}$} & \multirow{2}{*}{ Primary phase } \\
\hline & $\mathrm{Si}_{3} \mathrm{~N}_{4}$ & $\mathrm{Li}_{3} \mathrm{~N}$ & $\mathrm{Y}_{2} \mathrm{O}_{3}$ & $\mathrm{CaF}_{2}$ & $\mathrm{~B}_{2} \mathrm{O}_{3}$ & & & \\
\hline $\mathrm{A}$ & 89.0 & 11.0 & - & - & - & 2073 & 3.0 & $\mathrm{LiSi}_{2} \mathrm{~N}_{3}$ \\
\hline B & 89.0 & 11.0 & - & - & - & 1973 & 2.9 & $\mathrm{LiSi}_{2} \mathrm{~N}_{3}$ \\
\hline $\mathrm{C}$ & 89.0 & 11.0 & - & - & - & 1873 & 2.0 & $\mathrm{LiSi}_{2} \mathrm{~N}_{3}$ \\
\hline $\mathrm{D}$ & 85.9 & 10.7 & 3.4 & - & - & 1873 & 3.0 & $\mathrm{LiSi}_{2} \mathrm{~N}_{3}$ \\
\hline $\mathrm{E}$ & 86.8 & 10.8 & - & 2.4 & - & 1873 & 2.9 & $\mathrm{LiSi}_{2} \mathrm{~N}_{3}$ \\
\hline $\mathrm{F}$ & 88.0 & 10.9 & - & - & 1.1 & 1873 & 2.9 & $\mathrm{LiSi}_{2} \mathrm{~N}_{3}$ \\
\hline
\end{tabular}

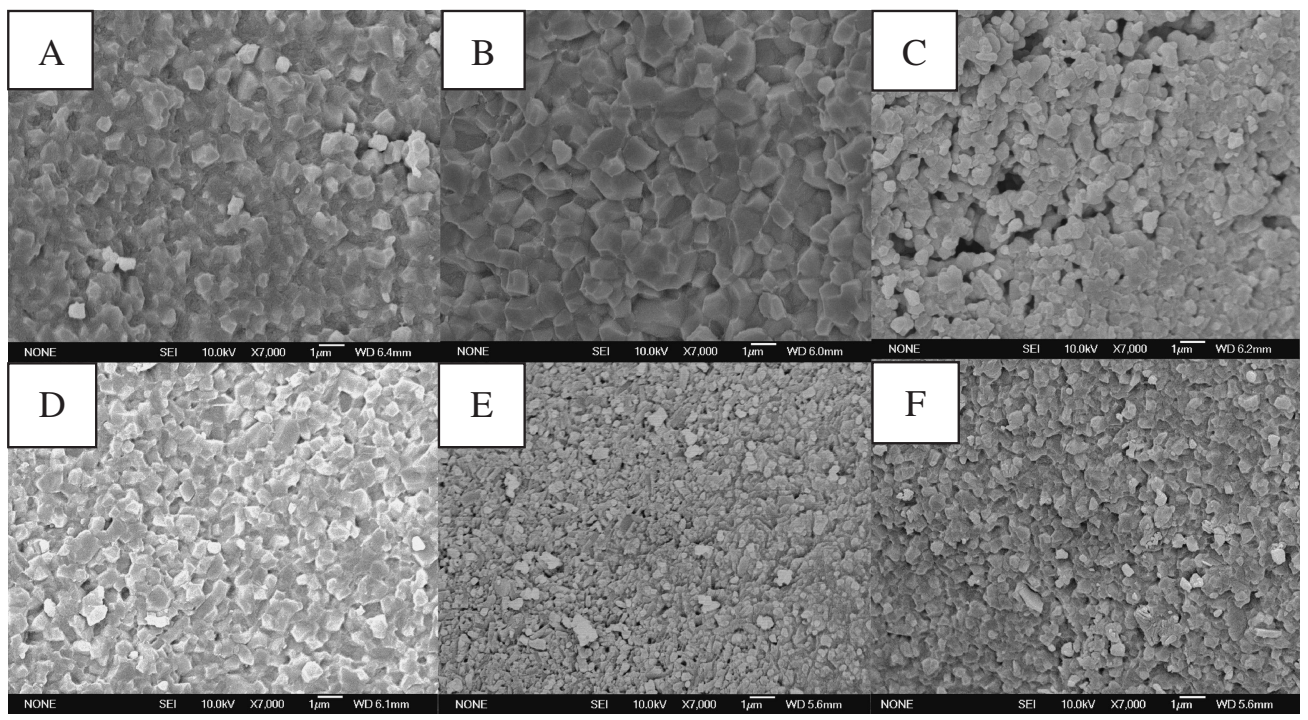

Fig. 1. SEM micrographs of fracture surface of sintered bodies of $\mathrm{LiSi}_{2} \mathrm{~N}_{3}$.

Both sides of each sintered sample were polished to a $9 \mu \mathrm{m}$ finish, and Au paste (Tanaka Kikinzoku, Japan) was applied to both sides of the sample by firing at $773 \mathrm{~K}$ for $30 \mathrm{~min}$ in $\mathrm{N}_{2}$. Subsequently, a circular Pt electrode was attached to each side of the sample before it was mounted on the support tube in a ProboStat (NorECs AS., Norway) measurement cell for electrochemical characterization (two-electrode measurements). ${ }^{14), 15)}$ Relatively strong spring loads were applied with alumina parts to hold the assembly together and to maintain contact between the sample and the electrodes. Each sample was heated to measurement temperature in dry nitrogen then maintained at this temperature for $0.5 \mathrm{~h}$ prior to the measurement of complex impedance.

The complex impedance measurements were performed using a Solartron 1260 impedance analyzer equipped with a Solartron 1296 dielectric interface. The measurement conditions were as follows: frequency range $2 \mathrm{mHz}-10 \mathrm{MHz}$, temperature range $293-673 \mathrm{~K}$, and flowing $\mathrm{N}_{2}$ gas atmosphere.

\section{Results and discussion}

The compositions of the starting powders, the sintering temperature, and the microstructural characteristics of the ashot-pressed materials (A-F) are summarized in Table 1. All materials contained mostly $\mathrm{LiSi}_{2} \mathrm{~N}_{3}$ and were relatively stable in air at room temperature. XRD analysis indicates that $\mathrm{LiSi}_{2} \mathrm{~N}_{3}$ is a primary phase and small amount of $\beta$ - $\mathrm{Si}_{3} \mathrm{~N}_{4}$ exists as a secondary phase in all materials. No other phase except the $\mathrm{LiSi}_{2} \mathrm{~N}_{3}$ and the $\beta-\mathrm{Si}_{3} \mathrm{~N}_{4}$ was detected by the XRD analysis in the case of undoped- $\mathrm{LiSi}_{2} \mathrm{~N}_{3}$ and $\mathrm{B}_{2} \mathrm{O}_{3}$-doped $\mathrm{LiSi}_{2} \mathrm{~N}_{3}$. On the other hand, a small amount of unidentified phases were detected by the XRD analysis in the case of $\mathrm{Y}_{2} \mathrm{O}_{3}$-doped $\mathrm{LiSi}_{2} \mathrm{~N}_{3}$ and $\mathrm{CaF}_{2}$-doped $\mathrm{LiSi}_{2} \mathrm{~N}_{3}$. Lattice parameter of each sample was obtained by fitting the XRD peak data using software Jade 7. The lattice parameter and the unit cell volume of all materials (A-F) were approximately the same. The total lattice volume change is less than $0.02 \%$. These results indicate that the amount of additive incorporated into $\mathrm{LiSi}_{2} \mathrm{~N}_{3}$ grain was very small in materials $\mathrm{D}-\mathrm{F}$.

The microstructures of the as-hot-pressed materials are shown in Fig. 1. As shown in the figure, no abnormal grain growth was observed, and the grains had an almost equiaxed form and size at a fine scale in all materials. The absence of residual porosity in the SEM images of materials A, B, D, E, and F indicates that these materials were almost fully densified. Material $\mathrm{C}$ had larger pores because its density was lower. Dense hot-pressed bodies were obtained at $1973-2073 \mathrm{~K}$ for undoped $\mathrm{LiSi}_{2} \mathrm{~N}_{3}$ and at $1873 \mathrm{~K}$ in the case of $\mathrm{Y}_{2} \mathrm{O}_{3}, \mathrm{CaF}_{2}$, and $\mathrm{B}_{2} \mathrm{O}_{3}$ addition. These results indicate that the addition of $\mathrm{Y}_{2} \mathrm{O}_{3}, \mathrm{CaF}_{2}$, and $\mathrm{B}_{2} \mathrm{O}_{3}$ promotes the densification of $\mathrm{LiSi}_{2} \mathrm{~N}_{3}$.

The complex impedance was measured to determine the conductivity. In general, the AC impedance of an ionic conductor measured by a two-probe method contains contributions from the grain interior, the grain boundaries, and the electrode-electrolyte interface, which can be illustrated in the complex plane by three successive arcs as shown in Fig. 2(b). ${ }^{16), 17)}$ The frequency increases from right to left in the plot. The arc at the highfrequency end of the spectrum represents the grain-interior resistivity, that at the middle of the spectrum is a consequence of the grain-boundary effect, and the low-frequency arc is assigned to the electrode response. An idealized equivalent circuit for polycrystalline ceramic materials corresponding to the impe- 
(a)

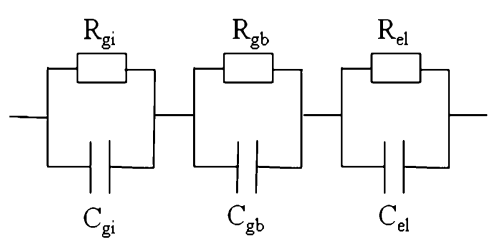

(b)

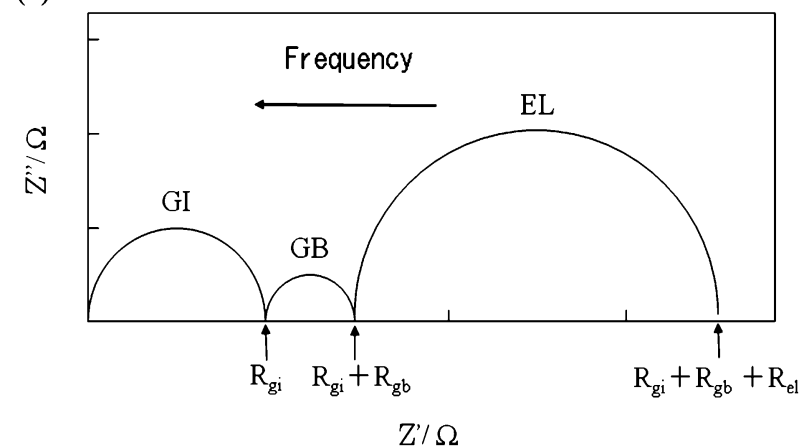

Fig. 2. Idealized equivalent circuit (a) and its corresponding impedance plot (b): $\mathrm{R}_{\mathrm{gi}}$ and $\mathrm{C}_{\mathrm{gi}}, \mathrm{R}_{\mathrm{gb}}$ and $\mathrm{C}_{\mathrm{gb}}$, and $\mathrm{R}_{\mathrm{el}}$ and $\mathrm{C}_{\mathrm{el}}$ represent the resistances and capacitances of the grain interior, grain boundaries, and the electrode-electrolyte interface, respectively.

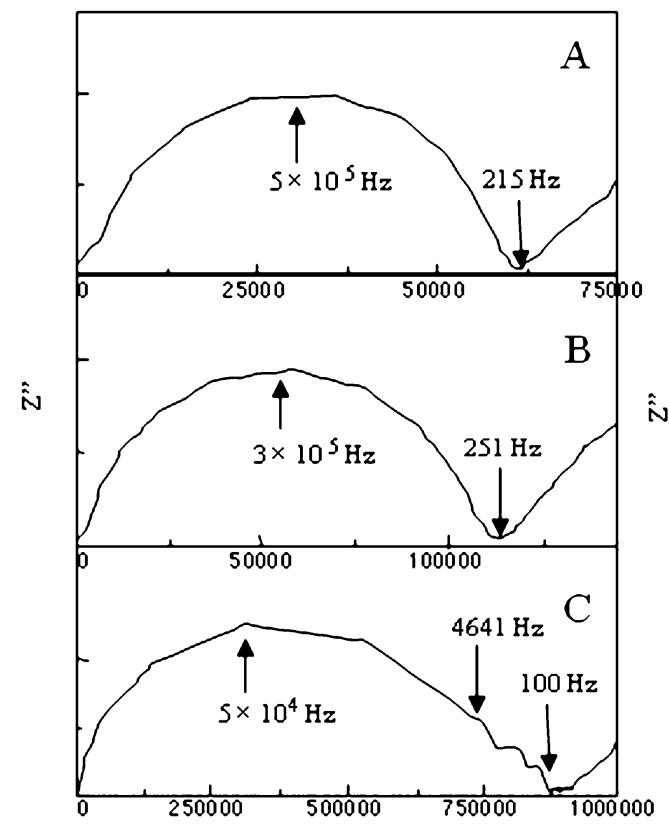

$z^{\prime}$

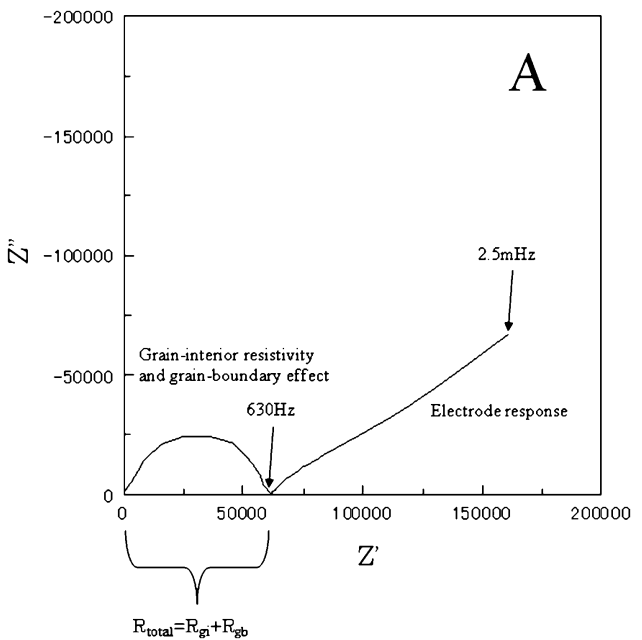

Fig. 4. Impedance spectra (recorded at $573 \mathrm{~K}_{\text {in }} \mathrm{N}_{2}$ ) for material A. The diameter of the semicircular arc was taken as the total resistance of the sample.

Fig. 3. Impedance spectra (recorded at $573 \mathrm{~K}$ in $\mathrm{N}_{2}$ ) of materials A-F.

dance plot is shown in Fig. 2(a). In practice, however, not all these arcs can be observed, depending on the nature of the sample and the measurement conditions.

Figure 3 illustrates complex impedance diagrams for $\mathrm{LiSi}_{2} \mathrm{~N}_{3}$ samples A-F recorded at $573 \mathrm{~K}$ in $\mathrm{N}_{2}$. Each complex impedance diagram $(2 \mathrm{mHz}-10 \mathrm{MHz})$ consists of a semicircular arc and a straight line. The shape of the arc changes with the sintering temperature and the addition of a sintering additive. In this context, the semicircular arc is attributed to $\mathrm{LiSi}_{2} \mathrm{~N}_{3}$ grains and grain boundaries, while the low-frequency straight line is considered to correspond to the sample-electrode charge transport process as shown in Fig. 4.
Figure 3 shows that for materials $\mathrm{A}-\mathrm{C}$ as the sintering temperature decreases, the shape of the semicircular arc changes. The arc for material $\mathrm{C}$ indicated greater resistance in the intermediate-frequency region (about $5 \mathrm{kHz}-100 \mathrm{~Hz}$ ) than that of materials $\mathrm{A}$ and $\mathrm{B}$. Material $\mathrm{C}$ was not fully densified because of the low temperature of sintering (see Table 1). Therefore, as shown in Fig. 1, many pores remained in the microstructure of material $\mathrm{C}$, particularly at the grain boundaries, after sintering. These pores may deteriorate the electrical properties at grain boundaries, ${ }^{18), 19)}$ and thus enhance the resistance there. In general, the resistance at grain boundaries contributes to the middle part of the spectrum shown in Fig. 2(b). The resistance at 


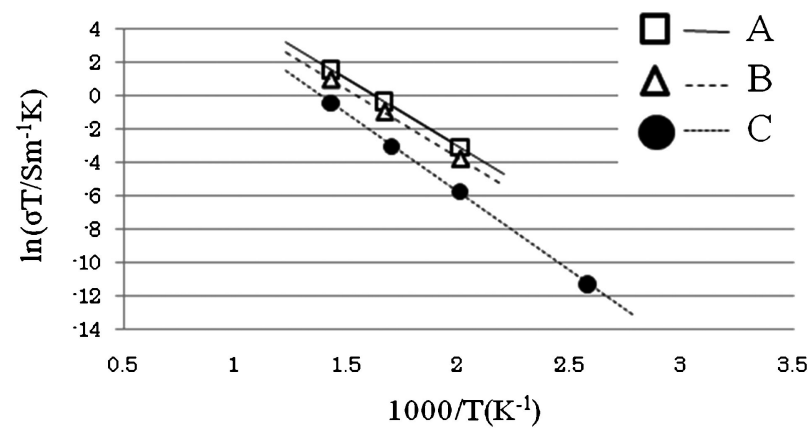

Fig. 5. Temperature dependences of ionic conductivities of materials A-C.

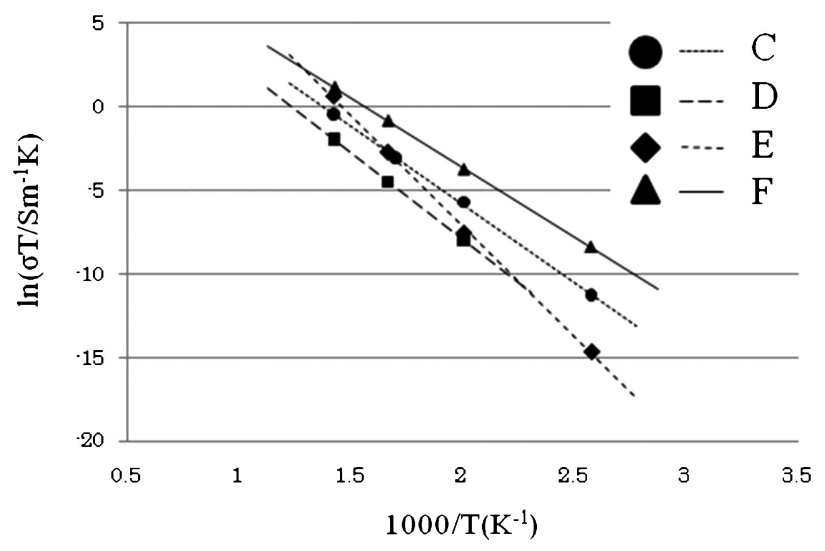

Fig. 6. Temperature dependences of ionic conductivities of materials C-F.

grain boundaries might contribute to resistance in the intermediate-frequency region, corresponding to the semicircular arc for material C.

As can be observed in Fig. 3, the shape of the semicircular arc for materials D-F also changed with the addition of a sintering additive. The arcs for $\mathrm{D}\left(\mathrm{Y}_{2} \mathrm{O}_{3}\right.$-doped material), and $\mathrm{E}\left(\mathrm{CaF}_{2}-\right.$ doped material) indicated greater resistance in the intermediatefrequency region (about $4 \mathrm{kHz}-1 \mathrm{~Hz}$ for $\mathrm{D}$ and about $5 \mathrm{kHz}-$ $10 \mathrm{~Hz}$ for $\mathrm{E}$ ) than that of material $\mathrm{A}$, which was undoped and fully densified. These results showed that a phase with significant resistance formed at the grain boundaries of materials D and E, because such a phase generally contributes to the middle of the spectrum. ${ }^{16), 17)}$ On the other hand, the resistance in the intermediate-frequency region for $\mathrm{F}\left(\mathrm{B}_{2} \mathrm{O}_{3}\right.$-doped material) was considerably less than that of materials $\mathrm{D}$ and $\mathrm{E}$, and the shape of the semicircular arc for $\mathrm{F}$ was similar to that for $\mathrm{A}$. These results show that the addition of $\mathrm{B}_{2} \mathrm{O}_{3}$ does not cause the formation of a high-resistance phase at the grain boundaries.

The total conductivity of each sample was estimated from the intersections between the extrapolated semicircular arc and the real axis. Yamane et al. reported that the electronic conductivity of $\mathrm{LiSi}_{2} \mathrm{~N}_{3}$ was less than $1 \%$ of the total conductivity at temperatures between 423 and $673 \mathrm{~K}^{4}{ }^{4}$ The experimental condition of complex impedance measurements was almost same as our experimental condition. So, we believe that most of the conductivity of $\mathrm{LiSi}_{2} \mathrm{~N}_{3}$ materials obtained in this study is caused by the migration of lithium ions as well as Yamane et al.'s report.

Figures 5 and $\mathbf{6}$ show the temperature dependences of the ionic conductivity for materials A-F, respectively. As shown in Figs. 5 and 6 , the plots of $\ln (\sigma T)$ against $1000 / T$ were found to be linear and closely fit the Arrhenius equation, $\sigma T=$
Table 2. Ionic conductivity and activation energy of lithium silicon nitrides

\begin{tabular}{ccc}
\hline Material & $\begin{array}{c}\sigma / \mathrm{S} \cdot \mathrm{m}^{-1} \\
(600 \mathrm{~K})\end{array}$ & $\begin{array}{c}E_{\mathrm{a}} \\
\left(\mathrm{kJ} \cdot \mathrm{mol}^{-1}\right)\end{array}$ \\
\hline A & $1.2 \times 10^{-3}$ & 66 \\
B & $6.3 \times 10^{-4}$ & 67 \\
$\mathrm{C}$ & $1.1 \times 10^{-4}$ & 78 \\
$\mathrm{D}$ & $1.9 \times 10^{-5}$ & 87 \\
$\mathrm{E}$ & $9.9 \times 10^{-5}$ & 110 \\
$\mathrm{~F}$ & $7.0 \times 10^{-4}$ & 69 \\
Ref. 4 $\left(\mathrm{LiSi}_{2} \mathrm{~N}_{3}\right)$ & $5.3 \times 10^{-3}$ & 64 \\
\hline
\end{tabular}

$A \exp \left(-E_{\mathrm{a}} / R T\right)$, where $A$ is the preexponential factor, $E_{\mathrm{a}}$ is the activation energy for conduction, and $R$ is the gas constant. Table 2 summarizes the conductivities at $600 \mathrm{~K}$ and the activation energies of conduction.

The ionic conductivity increased and the activation energy of ionic conduction decreased with increasing sintering temperature and material density, shown by the results for materials $\mathrm{A}-\mathrm{C}$. The high ionic conductivity of materials $\mathrm{A}$ and $\mathrm{B}$ may be caused by the increased density of the sintered sample, which enhances grain boundary conductivity, and the low activation energy. Material $\mathrm{C}$ has the lowest conductivity and the largest activation energy among materials A-C, probably because its structure has many large pores, which block the migration of lithium ions.

Although the densities of materials D and $\mathrm{E}$ were higher than that of material $\mathrm{C}$, their conductivities were lower than that of material $\mathrm{C}$, and their activation energies were larger than that of material $\mathrm{C}$. These findings might be due to the formation of a phase with significant resistance at the grain boundaries of materials D and E. The unidentified phases detected by XRD analysis might be the phase with significant resistance. This phase blocks the migration of lithium ions, and thus decreases the ionic conductivity. In contrast, the conductivity of material $\mathrm{F}$ is higher than that of material $\mathrm{C}$, and its activation energy is smaller than that of material $\mathrm{C}$, probably due to the increase in the density of material $\mathrm{F}$ upon sintering without the formation of a phase with significant resistance at the grain boundaries. Accordingly, the conductivity of material $F$ increased to a value comparable to that of the undoped and fully densified material B.

Although the amount of additive incorporated into $\mathrm{LiSi}_{2} \mathrm{~N}_{3}$ grain was very small in materials $\mathrm{D}-\mathrm{F}$, we cannot rule out the possibility that the incorporation of the additive into $\mathrm{LiSi}_{2} \mathrm{~N}_{3}$ grain might change the $\mathrm{LiSi}_{2} \mathrm{~N}_{3}$ grain conductivity and the total conductivity. Further investigation and more detailed characterization are under progress to elucidate this point.

The conductivity of material A (undoped $\mathrm{LiSi}_{2} \mathrm{~N}_{3}, 1.2 \times 10^{-3}$ $\mathrm{S} \cdot \mathrm{m}^{-1}$ at $\left.600 \mathrm{~K}\right)$ was the highest and its activation energy $(66 \mathrm{~kJ} / \mathrm{mol})$ was the lowest among the compounds prepared in this study. The high ionic conductivity can be explained as follows. The density of material A was the highest among materials $\mathrm{A}$ to $\mathrm{F}$, and thus the ionic conductivity at grain boundaries was enhanced by the greatest amount. Moreover, no sintering additive was added to material $\mathrm{A}$, therefore its structure did not have a high-resistance phase resulting from a sintered additive at the grain boundaries. Yamane et al. reported the preparation and ionic conductivity of $\mathrm{LiSi}_{2} \mathrm{~N}_{3}$. They prepared $\mathrm{LiSi}_{2} \mathrm{~N}_{3}$ at a low temperature of $1475 \mathrm{~K}$ in a nitrogen gas flow for a short duration to minimize lithium vaporization. ${ }^{4}$ Although the sintering temperature of material A in this study was very high $(2073 \mathrm{~K})$, the conductivity of A was comparable to that of Yamane et al.'s material. The high ionic conductivity may have 
been caused by the hot pressing at $20 \mathrm{MPa}$ in a $\mathrm{N}_{2}$ atmosphere ( $0.10 \mathrm{MPa})$. In this study, lithium vaporization might have been suppressed by the hot pressing.

\section{Conclusions}

The effect of sintering temperature and sintering additives on the ionic conductivity of $\mathrm{LiSi}_{2} \mathrm{~N}_{3}$ was studied by performing complex impedance measurements. $\mathrm{LiSi}_{2} \mathrm{~N}_{3}$ materials were prepared by the reaction of $\mathrm{Li}_{3} \mathrm{~N}, \mathrm{Si}_{3} \mathrm{~N}_{4}$, and sintering additives at temperatures of $1873-2073 \mathrm{~K}$. Dense hot-pressed bodies were obtained at $1973-2073 \mathrm{~K}$ in the case of undoped $\mathrm{LiSi}_{2} \mathrm{~N}_{3}$ and at $1873 \mathrm{~K}$ in the case of $\mathrm{Y}_{2} \mathrm{O}_{3}, \mathrm{CaF}_{2}$, and $\mathrm{B}_{2} \mathrm{O}_{3}$ addition. These results indicated that the addition of $\mathrm{Y}_{2} \mathrm{O}_{3}, \mathrm{CaF}_{2}$, or $\mathrm{B}_{2} \mathrm{O}_{3}$ promotes the densification of $\mathrm{LiSi}_{2} \mathrm{~N}_{3}$. All the obtained materials were relatively stable in air. The ionic conductivity of the materials was investigated from near-ambient temperature up to $673 \mathrm{~K}$ by complex impedance spectroscopy in a $\mathrm{N}_{2}$ atmosphere. The complex impedance diagram $(2 \mathrm{mHz}-10 \mathrm{MHz})$ of each material consisted of a semicircular arc and a straight line. The shape of the arc in the complex impedance diagram changed with the sintering temperature and with the addition of a sintering additive. The semicircular arc was attributed to $\mathrm{LiSi}_{2} \mathrm{~N}_{3}$ grains and grain boundaries, while the low-frequency straight line was considered to be due to the sample-electrode charge transport process.

The ionic conductivity was enhanced greatly with increasing sintering temperature. The improved ionic conductivity might have been caused by the decrease in the size of pores in the microstructure with the increased density of the sintered sample, which enhanced the grain boundary conductivity. In porous $\mathrm{LiSi}_{2} \mathrm{~N}_{3}$ ceramics, the pores inhibit the movement of carriers; thus, porous $\mathrm{LiSi}_{2} \mathrm{~N}_{3}$ ceramics have lower conductivity than dense $\mathrm{LiSi}_{2} \mathrm{~N}_{3}$ ceramics. The conductivity was also affected by the addition of sintering additives. When the sintering temperature was constant at $1873 \mathrm{~K}$, although the conductivities of $\mathrm{Y}_{2} \mathrm{O}_{3}$-doped $\mathrm{LiSi}_{2} \mathrm{~N}_{3}$ and $\mathrm{CaF}_{2}$-doped $\mathrm{LiSi}_{2} \mathrm{~N}_{3}$ were lower than that of undoped $\mathrm{LiSi}_{2} \mathrm{~N}_{3}$, the conductivity of $\mathrm{B}_{2} \mathrm{O}_{3}$-doped $\mathrm{LiSi}_{2} \mathrm{~N}_{3}$ was higher than that of undoped $\mathrm{LiSi}_{2} \mathrm{~N}_{3}$. The enhanced conductivity of $\mathrm{B}_{2} \mathrm{O}_{3}$-doped $\mathrm{LiSi}_{2} \mathrm{~N}_{3}$ can be attributed to the increase in the density of the sintered material without the formation of a phase of significant resistance at the grain boundaries, which thus enhanced the grain boundary conductivity.
Undoped $\mathrm{LiSi}_{2} \mathrm{~N}_{3}$, which had the highest density among the materials investigated in this study, had the highest lithium ionic conductivity $\left(1.2 \times 10^{-3} \mathrm{~S} \cdot \mathrm{m}^{-1}\right.$ at $\left.600 \mathrm{~K}\right)$ and the lowest activation energy $(66 \mathrm{~kJ} / \mathrm{mol})$.

\section{References}

1) A. Rabenau, Solid State Ionics, 6, 277-293 (1982).

2) H. Yamane, S. Kikkawa and M. Koizumi, J. Solid State Chem., 71, 1-11 (1987).

3) H. Yamane, S. Kikkawa and M. Koizumi, Solid State Ionics, 15, 51-54 (1985).

4) H. Yamane, S. Kikkawa and M. Koizumi, Solid State Ionics, 25, 183-191 (1987).

5) P. Hartwig, W. Weppner and W. Wichelhaus, Mater. Res. Bull., 14, 493-498 (1979).

6) W. Weppner, P. Hartwig and A. Rabenau, J. Power Sources, 6, 251-259 (1981).

7) J. David, Y. Laurent, J. P. Charlot and J. Lang, Bull. Soc. Fr. Mineral. Cristallogr., 96, 21-24 (1973).

8) M. Orth and W. Schnick, Z. Anorg. Allg. Chem., 625, 14261428 (1999).

9) A. J. Anderson, R. G. Blair, S. M. Hick and R. B. Kaner, J. Mater. Chem., 16, 1318-1322 (2006).

10) M. S. Bhamra and D. J. Fray, J. Mater. Sci., 30, 5381-5388 (1995).

11) R. Juza, H. H. Weber and E. Meyer-Simon, Z. Anorg. Allg. Chem., 273, 48-64 (1953).

12) A. T. Dadd and P. Hubberstey, J. Chem. Soc., Dalton Trans., 2175-2179 (1982).

13) V. Ischenko, L. Kienle and M. Jansen, J. Mater. Sci., 37, 53055317 (2002).

14) P. I. Dahl, R. Haugsrud, H. L. Lein, T. Grande, T. Norby and M. Einarsrud, J. Eur. Ceram. Soc., 27, 4461-4471 (2007).

15) T. Norby and M. Hartmanova, Solid State Ionics, 67, 57-64 (1993).

16) Y. Li, M. Liu, J. Gong, Y. Chen, Z. Tang and Z. Zhang, Mater. Sci. Eng., B, 103, 108-114 (2003).

17) T. S. Zhan, J. Ma, Y. Z. Chen, L. H. Luo, L. B. Kong and S. H. Chan, Solid State Ionics, 177, 1227-1235 (2006).

18) S. Li and B. Bergman, J. Eur. Ceram. Soc., 29, 1139-1146 (2009).

19) T. Zeng, X.-L. Dong, C.-L. Mao, Z.-Y. Zhou and H. Yang, J. Eur. Ceram. Soc., 27, 2025-2029 (2007). 